\title{
Early onset of propriospinal-like myoclonus in a child following a vertebral fracture
}

自

\section{Figure Spinal cord MR}
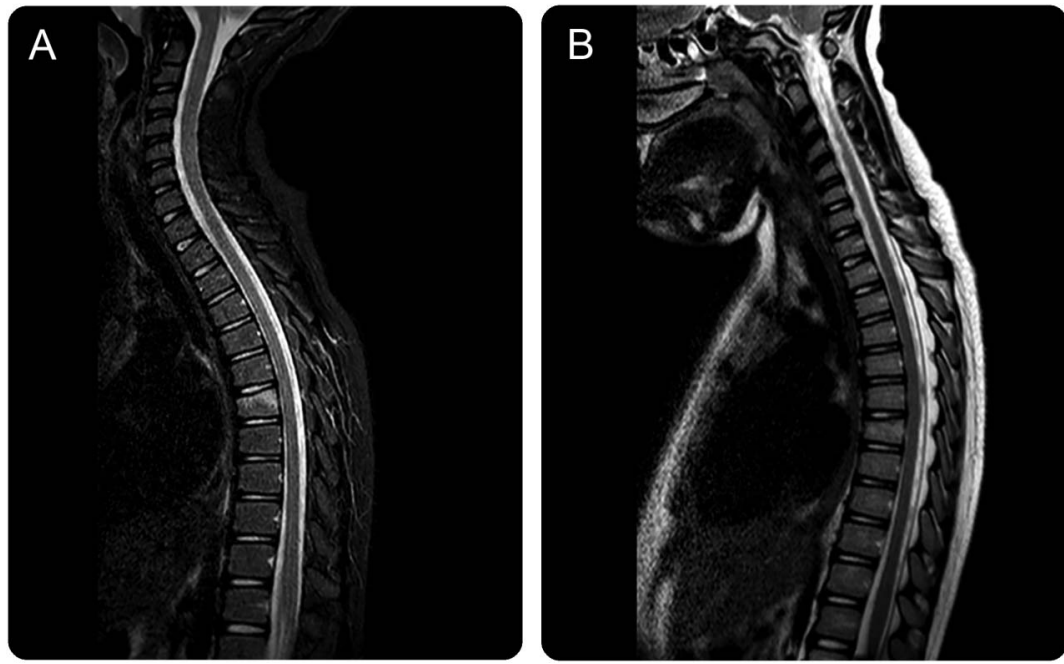

(A) Spinal MRI performed the day after the back trauma shows a wedge fracture with edema of the T7 vertebral body without evidence of spinal parenchymal lesions. (B) Spinal MRI performed a month after the back trauma shows resolution of edema of the T7 vertebral body.

Supplemental data at Neurology.org
A 9-year-old girl presented with trunk and limb myoclonic status (video at Neurology.org) that started immediately after back trauma that caused a T7 vertebral body fracture without spinal involvement (figure). Myoclonic status became more severe after tactile stimuli and spontaneously disappeared within 32 hours. The jerk-locked back-averaging analysis excluded a cortical origin and the somatosensory evoked potentials, performed after 36 hours, were normal. Full neuropsychological examination and Child Behavior Checklist scores were within normal limits. This represents a novel presentation of early posttraumatic propriospinal-like myoclonus in a child. We hypothesize a transient spinal impairment due to mechanical compression. ${ }^{1,2}$

Carlotta Facini, MD, Marina Barsacchi, MD, Benedetta Piccolo, MD, Emanuela Claudia Turco, MD, Francesco Pisani, $M D$

From the Child Neuropsychiatry Unit, Neuroscience Department (C.F., M.B., F.P.), University of Parma; and Child Neuropsychiatry Unit, Mother and Child Department (B.P., E.C.T., F.P.), University-Hospital of Parma, Italy.

Study funding: No targeted funding reported.

Disclosure: The authors report no disclosures relevant to the manuscript. Go to Neurology.org for full disclosures.

Correspondence to Dr. Facini: carlottafacini@gmail.com

1. Manconi M, Sferrazza B, Iannacone S, Massimo A, Zucconi M, Ferini-Strambi L. Case of symptomatic propriospinal myoclonus evolving toward acute "myoclonic status." Mov Disord 2005;20:1646-1650.

2. Chung EJ, Kim SJ, Lee WY, Bae JS, Kim EG, Pang SH. Four cases with peripheral trauma induced involuntary movements. J Mov Disord 2010;3:39-41. 


\section{Neurology}

\section{Early onset of propriospinal-like myoclonus in a child following a vertebral fracture}

Carlotta Facini, Marina Barsacchi, Benedetta Piccolo, et al.

Neurology 2016;87;956

DOI 10.1212/WNL.0000000000003053

\section{This information is current as of August 29, 2016}

\section{Updated Information \& Services}

Supplementary Material

\section{References}

Subspecialty Collections

Permissions \& Licensing

Reprints including high resolution figures, can be found at: http://n.neurology.org/content/87/9/956.full

Supplementary material can be found at: http://n.neurology.org/content/suppl/2016/08/29/WNL.0000000000003 053.DC1

This article cites 2 articles, 0 of which you can access for free at: http://n.neurology.org/content/87/9/956.full\#ref-list-1

This article, along with others on similar topics, appears in the following collection(s): EEG; see Epilepsy/Seizures

http://n.neurology.org/cgi/collection/eeg_see_epilepsy-seizures EMG

http://n.neurology.org/cgi/collection/emg

MRI

http://n.neurology.org/cgi/collection/mri

Myoclonus

http://n.neurology.org/cgi/collection/myoclonus

Spinal cord trauma

http://n.neurology.org/cgi/collection/spinal_cord_trauma

Information about reproducing this article in parts (figures,tables) or in its entirety can be found online at:

http://www.neurology.org/about/about_the_journal\#permissions

Information about ordering reprints can be found online:

http://n.neurology.org/subscribers/advertise

Neurology ${ }^{\circledR}$ is the official journal of the American Academy of Neurology. Published continuously since 1951, it is now a weekly with 48 issues per year. Copyright () 2016 American Academy of Neurology. All rights reserved. Print ISSN: 0028-3878. Online ISSN: 1526-632X.

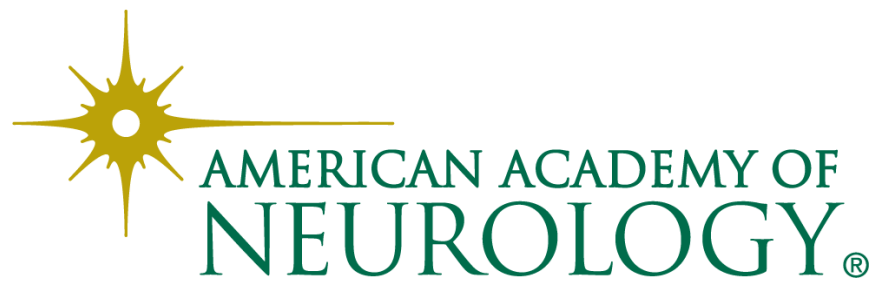

